\title{
NIETZSCHE E SUA COMPREENSÃO EXTRA-MORAL DA EXPERIÊNCIA ORIGINÁRIA DA BEATITUDE EVANGÉLICA DE JESUS
}

\author{
Renato Nunes Bittencourt \\ Universidade Federal do Rio de Janeiro
}

\begin{abstract}
The article analyzes the axiologic distinction established by Nietzsche enters the gospel practical of Jesus and the distortion of the same one for the institutionalization of the Christian morality. By Nietzsche, one becomes if an interpretation immanent of the religious message of Jesus, whose doctrine is a possibility of if reaching the beatitude in the scope of the proper life, and a promise does not stop beyond the world.
\end{abstract}

KEYWORDS: Jesus, Gospel Practical, Christian Experience, Beatitude, Amor Fati.

RESUMO: 0 artigo analisa a distinção axiológica estabelecida por Nietzsche entre a prática evangélica de Jesus e a distorção da mesma pela institucionalização da moralidade cristã. Via Nietzsche, faz-se se uma interpretação imanente da mensagem religiosa de Jesus, cuja doutrina é uma possibilidade de se alcançar a beatitude no âmbito da própria vida, e não uma promessa para além do mundo.

PALAVRAS-CHAVE: Jesus, Prática Evangélica, Vivência Crística, Beatitude, Amor Fati.

Apesar de ruptura axiológica e existencial de Nietzsche com a moralidade cristã instituída e suas manifestações na civilização ocidental, tal circunstância não motiva a desvalorização, nas suas obras, da figura e do legado de Jesus de Nazaré, o inspirador do desenvolvimento da religião cristã, ainda que teologicamente distorcida no decorrer dos séculos pela ação dos detentores do poder eclesiástico. Podemos afirmar que o ensaio $O$ Anticristo (redigido em 1888) é a obra na qual Nietzsche dedica suas considerações mais amplas sobre a práxis religiosa de Jesus e a adaptação de tal legado pelos 
seguidores vindouros, mas em algumas das suas obras anteriores encontramos considerações importantes sobre a figura de Jesus, que de algum modo antecipam algumas das problematizações dos seus escritos derradeiros. Com efeito, ao versar no $\S 475$ de Humano, demasiado Humano sobre as qualidades do povo judeu e as suas vicissitudes históricas, Nietzsche se refere a Jesus (designado no texto como "Cristo") como "o mais nobre dos homens" (2002, p. 258). Em tal obra, Nietzsche não fornece qualquer outro elemento indicativo mais preciso para a concessão do adjetivo de "nobre" para Jesus, mas o processo argumentativo apresentado ao longo d' $O$ Anticristo certamente favorecem o esclarecimento da visão positiva que Nietzsche realiza acerca do Nazareno.

Um dos focos narrativos mais importantes d'O Anticristo consiste na polêmica que Nietzsche estabelece com Ernest Renan, renomado historiador francês que dedicara grande parte de sua vida intelectual no vasto estudo sobre as origens do Cristianismo nas suas conjunturas históricas e teológicas, oferecendo ao público o fruto de tais esforços intelectuais através da edição de História das Origens do Cristianismo, em especial na célebre Vida de Jesus, obra que o volume introdutório do portentoso estudo. Nietzsche demonstra continuamente uma grande aversão pela obra de Renan, conforme podemos ver em 2006, p. 63, onde Nietzsche diz: "Renan - Teologia, ou a corrupção da razão pelo 'pecado original' (o cristianismo)". Todavia, é justo ressaltar que Nietzsche reflete nas suas críticas tardias ao Cristianismo alguns pontos cruciais da historiografia renaniana, mas é justamente essa fixação do historiador francês pelas categorias de "herói” e "gênio, esses grosseiros erros do "bufão" in psychologicis (2007, p. 35), que motivam as irônicas diatribes nietzschianas. Uma leitura atenta da obra de Renan nos permite constatar a sua extrema competência na narrativa historiográfica da gênese do movimento cristão; mais ainda, Renan elabora uma compreensão da natureza histórica de Jesus que apresenta rupturas com o quadro teológico estabelecido, e foram essas intuições que influenciaram positivamente a formulação nietzschiana da "psicologia crística", ainda que o filósofo tenha manifestado publicamente apenas a sua aversão aos pretensos erros de interpretação de Renan. É inegável que os estudos de Renan influenciaram as teses nietzschianas acerca da atividade evangélica de Jesus, assim como a formulação de um método exegético para a compreensão dessa experiência religiosa, apesar dos acréscimos que a tradição da moralidade cristã lhe inseriu. Com efeito, tal como Renan salienta 
Que os evangelhos são uma parte lendários, isso é evidente, porque estão cheios de milagres e de sobrenatural; mas há lendas de lendas. Ninguém duvida das passagens principais da vida de São Francisco de Assis, embora a sua vida apresente a cada passo o sobrenatural. (RENAN, 1915, p. XVII-XVIII).

A citação nietzschiana é uma prova textual que demonstra a influência exercida por Renan na formulação do seu estudo sobre a práxis evangélica de Jesus e a sua relação com a axiologia da sociedade judaica, bem como a possibilidade de se alcançar uma compreensão intrínseca do tipo psicológico de Jesus, objetivo que mais lhe importa:

O que me importa é o tipo psicológico do Redentor. Afinal, ele pode estar contido nos evangelhos apesar dos evangelhos, ainda que mutilado ou carregado de traços alheios: como o de Francisco de Assis está conservado em suas lendas, apesar de suas lendas. Não a verdade quanto ao que fez, o que disse, como realmente morreu; mas a questão de o seu tipo ser concebível, de haver sido "transmitido" (NIETZSCHE, 2007, p.35)

Conforme Nietzsche expõe no decorrer d' O Anticristo, aquela que seria a autêntica figura histórica de Jesus estaria fixada em seu tipo psicológico, suposto que esse tivesse sido transmitido, uma vez despojado dos traços estranhos e incongruentes com que a instituição cristã o teria axiologicamente "desfigurado". Essa é a maneira pela qual seria elaborada a "Psicologia do Redentor" proposta por Nietzsche, que motiva uma forte polêmica acerca da definição da personalidade de Jesus, destituída de todo traço transcendente que lhe fora concedido pela visão de mundo cristã. $\mathrm{O}$ elemento que indubitavelmente é mais surpreendente nesse processo da formulação nietzschiana do tipo psicológico de Jesus é que o filósofo alemão, apesar da sua radical incompatibilidade com a valoração moral cristã, realiza uma exegese sobre no que consiste a vida e a práxis de Jesus, considerando-o através de um enfoque imanente. O Nazareno efetivara uma prática de vida pautada na valoração intensiva da realidade, utilizando como instâncias sustentadoras de sua doutrina existencial a necessidade do indivíduo, sob quaisquer circunstâncias, vivenciar plenamente os sentimentos de amor, de harmonia e de alegria, afetos potentes que, no âmbito da experiência evangélica originária, favorecem o alcance da beatitude na vida prática. 
Posta esta questão preliminar, eis então o grande questionamento de Nietzsche: o que fora realmente Jesus enquanto pessoa e tipo psicológico? Um "herói”, um "gênio"? Ora, estas são as definições propostas por Ernest Renan na sua cristologia. Para Nietzsche, essa perspectiva defendida pelo pensador francês seria um enorme equívoco, pois a vida e a obra evangélica de Jesus contrariavam toda a idéia de "herói" ou "gênio", conforme pretendido de forma tão insistente por Renan (2007, p. 35-36). Tal circunstância evidencia a forte valoração romântica que Renan insere em sua argumentação, metodologia que impede a compreensão precisa da realidade do mundo judaico em que vivia Jesus. Para a compreensão do cerne de tais interpretações, vejamos como argumenta Renan, primeiramente acerca da idéia da existência de traços heróicos em Jesus:

É agora o incomparável herói da Paixão, o fundador dos direitos da consciência livre, o perfeito modelo, que todas as almas amarguradas que sofrem hão de estudar para se fortificarem e consolarem (RENAN, 1915, p. 312)

Nietzsche se escandaliza com o postulado da existência de traços heróicos na personalidade do Nazareno pelo seguinte motivo: pela palavra "herói” pressupõe-se uma disposição individual para ação prática, a partir do projeto de se transformar extensivamente uma dada situação, seja numa batalha ou numa circunstância histórico-social. Um herói se caracteriza pelo projeto de superar os seus adversários mediante o uso da força física e também da inteligência. É praticamente inconcebível visualizarmos a imagem de Jesus como um adepto da luta armada em prol do estabelecimento da justiça entre os homens, pois tal procedimento contrariaria os seus preceitos beatíficos de não-resistência. Ora, Jesus não pretendia destruir o jugo romano sobre Israel através de uma revolução social marcada pela imposição do vigor físico, da força corporal. O projeto evangélico de Jesus não consistia no questionamento e na supressão da ordem política estabelecida, mas na instauração do estado de alegria mediante a prática doadora de amor, circunstância que retira a pessoa das picuinhas corriqueiras da realidade. ${ }^{1}$

\footnotetext{
1 Podemos ver um exemplo prático de tal perspectiva na passagem dos Evangelhos em que os fariseus, indagando sofisticamente a Jesus se era justo ou não que os judeus pagarem o tributo estabelecido pelos romanos recebem como resposta do Nazareno a célebre sentença: "Dai a César o que é de César, e a Deus o que é de Deus" (Mateus, 22, 15-22; Marcos, 12, 13-17).
} 
Nessas condições, aquilo que Jesus efetivamente propunha era a transformação do enfoque valorativo do indivíduo em relação àquilo que ele realmente considerava como os seus objetivos existenciais no seu cotidiano. A disposição beatífica de Jesus ocorre numa dimensão para além da esfera social das relações políticas, pois estas, em decorrência dos sectários e dos interesses particulares, podem prejudicar o estabelecimento de uma vivência harmoniosa conveniente no estabelecimento de uma relação interpessoal. Tal problema, portanto, contradiria o evangelho de Jesus, que precisamente é um processo de transmutação dos afetos ressentidos em uma experiência de abertura para o outro, numa mística interação doadora de vida, de alegria.

O fato do conceito de "herói” não coadunar com o tipo psicológico de Jesus, segundo a perspectiva nietzschiana, não significaria, todavia, uma invalidação de sua obra evangélica, pois o propósito maior da práxis evangélica realizada pelo Nazareno consistia em levar os seus adeptos a um nível de compreensão da existência em que os estados afetivos turbulentos fossem poderosamente enfraquecidos, a fim de que a criação e o amor transbordassem de pessoa a pessoa. A não-reatividade de Jesus diante das atribulações impostas por seus sicários representaria, na verdade, a sua capacidade do superar todo ímpeto de ressentimento e reatividade, pois, em decorrência de sua manifestada beatitude, nenhum estímulo externo agressivo poderia retirá-lo desse estado de interatividade imediata com o "divino".

Conforme destacamos anteriormente, outro elemento problemático destacado por Nietzsche acerca da cristologia de Ernest Renan decorreria da sua tentativa de enquadrar a personalidade de Jesus na categoria de "Gênio". Como o historiador francês destaca: "Como todos os homens de gênio, Jesus não tratava senão da alma” (RENAN, 1945, p. 46). ${ }^{2}$ Nietzsche refuta tal tese renaniana por considerar de forma peremptória que não condizia com a realidade judaica o conceito de "gênio", conceito muito caro ao espírito romântico, mas que não poderia ser aplicado de forma anacrônica a um âmbito histórico-social indiferente aos parâmetros valorativos da cultura

\footnotetext{
2 Inclusive, acerca da idéia de "gênio" na consciência cristã, podemos destacar ainda a inegavelmente bela e monumental obra de François-René de Chateaubriand ( $O$ Gênio do Cristianismo), na qual o autor se propõe a exaltar a tradição cultural cristã como uma manifestação da superioridade do espírito humano diante dos valores culturais do mundo antigo que, mesmo criando obras merecedoras da imortalidade, não fazem frente a tudo aquilo de belo e grandioso originado a partir da idéia cristã. Chateaubriand propõe até mesmo uma espécie de formulação de uma estética cristã, ao analisar grandes obras artísticas influenciadas pela visão de mundo cristã, enaltecendo-as como a culminação da beleza, da virtude e da verdade.
} 
greco-romana e mesmo do judaísmo de traços helenizantes, instâncias que não descuravam do cultivo de si mediante a aquisição de uma educação formal, modelo pedagógico incompatível com a realidade social da qual brotou Jesus, perifericamente alheia ao âmbito valorativo da sociedade de corte hierosolimita. Podemos esclarecer essa idéia se compreendermos que a formação do "homem de gênio" pressupõe a disposição intrínseca da cultura da qual se faz parte para o florescimento de uma série de elementos que concedam ao indivíduo e ao seu povo a realização de obras intelectuais e artísticas que expressam a singularidade do seu criador. Jesus, nessas circunstâncias, de modo algum se encontrava associado aos valores culturais que possibilitam o surgimento da tipologia do "gênio", pois que o Nazareno se expressava através de verdades interiores, não de conceitos lógicos demonstrativos, a maneira de um dialético que pretende persuadir os seus interlocutores através da racionalidade discursiva e dos floreios retóricos da linguagem. Esse processo intuitivo de desvelamento de uma "verdade interior”, para muito além da esfera da lógica formal e da racionalidade, não pode ser adquirida pela cultura estabelecida, pelo estudo e pela erudição, mas pelo "coração", pois é uma experiência da interioridade. O fundamento da práxis evangélica não pode ser demonstrado pela racionalidade, pois é uma vivência beatífica que está acima dessas categorias cognitivas. Tal simbolismo está fora de toda religião, de todos os conceitos do culto, da história, da ciência natural, da experiência do mundo, da política, da psicologia, dos livros, da arte; o saber de Jesus é justamente a pura tolice quanto ao fato de que algo assim existe, destaca Nietzsche (2007, p. 39).

Jesus é indiferente ao âmbito da "cultura" estabelecida socialmente, pois a sua vivência espiritual foi adquirida mediante a sua interiorização psico-afetiva, cujo resultado mais evidente se dá na supressão de toda atividade mental dedutiva. Esse processo intuitivo de desvelamento de uma verdade interior, para muito além da esfera da lógica, da racionalidade, não pode ser adquirida pela cultura formal e pela erudição, mas pelo "coração", pois é uma experiência da interioridade. Desse modo, Jesus é incapaz de negar a "cultura", pois nem mesmo a conhece como tal; a cultura não teria nenhum significado para ele (FREZZATTI Jr., 2006, p.166). Aliás, já fica claro aqui que em Jesus não há o traço negativo em relação ao mundo, e mesmo que ele não o afirme na sua esfera social (extensiva), ao menos ele não propõe a sua negação, algo impossível para o Nazareno (NIETZSCHE, 2007, p. 39). 
Nietzsche pretende então conceder uma definição categórica para a personalidade de Jesus, definição essa que seria a senha para a compreensão do grande enigma que foi a vida do Nazareno: este seria um "idiota", não na sua depreciativa conotação usual do senso comum, mas no sentido original do termo grego, ou seja, de uma pessoa "indiferente", alheia aos valores estabelecidos usualmente pela sociedade e por seus costumes instituídos, por não compactuar com as circunstâncias que envolvem a realidade cotidiana (NIETZSCHE, 2007, p. 35-36). Dessa maneira, ao delinear o tipo psicológico de Jesus através do conceito de "idiota”, Nietzsche demonstra no Fragmento Póstumo 15 [9] da primavera de 1888 uma importante filiação a Dostoiévski, cujo pensamento lhe serve de apoio para a sua própria contraposição perante a erudita cristologia de Renan:

Jesus - Dostoiévski - Eu conheço apenas um psicólogo que viveu num mundo onde o Cristianismo é possível, onde um Cristo pode surgir a qualquer momento. É Dostoievski. Ele adivinhou Cristo: - e ele permaneceu instintivamente protegido da representar esse tipo com a vulgaridade de Renan (NIETZSCHE, 1980, p. 409)

Dostoiévski, no seu romance $O$ Idiota, através da figura do singularíssimo príncipe Míchkin, apresenta a beatífica personalidade do tipo humano incapaz de compreender e adquirir domínio cabal sobre as vicissitudes externas que o rodeiam. Sufocado numa atmosfera social marcada pelo oportunismo dos indivíduos e pelo ímpeto destes em fazer imperar os seus desejos egoístas, a mescla de inocência e sublimidade de Míchkin se tornam instrumentos que se voltam contra ele mesmo, pois sua maior "culpa" foi a de não pertencer ao jogo de mesquinharia dos seus interlocutores. Todavia, somente quem se destaca da "moral de rebanho", submetida axiologicamente aos parâmetros da sociedade e das suas instituições normativas é capaz de intuir a essência crística e a distorção operada pelo estabelecimento eclesiástico no decorrer da história. Com efeito, o tipo “idiota” está mais próximo da vivência evangélica do que a falsa consciência devota "cristã", que prega um Cristianismo deformado, prenhe de calúnia e deturpado, ou seja, um verdadeiro "Anticristo" (DOSTOIÉVSKI, 2002, p. 606).

O "idiota” é uma pessoa sem igual no mundo, pois a sua axiologia não corresponde ao padrão estabelecido pela moda e pelos costumes sociais. 
Imputado como "tolo" diante de uma dimensão social que baseia os seus valores por critérios quantitativos (acúmulo de bens, constituição do padrão familiar, busca por honrarias e privilégios), o "idiota" possui uma forte disposição para a "nobreza de espírito", "nobreza” que, aliás, pode também perfeitamente se manifestar na sua vida como uma dádiva material, um título honorífico, tal como o próprio príncipe Míchkin. Conforme argumenta Anton Uhl, neste mundo de Dostoievski reencontra Nietzsche o Cristianismo mais autêntico, que, segundo sua consideração, Paulo perverteu tão completamente: incapaz de encontrar dentro de si o "Reino de Deus", ele o transferiu para o "Além", ensinou o juízo e criou um Cristianismo que faz guerra, condena, tortura, jura, odeia (UHL, 1981, p.53) É nesse contexto que podemos entender a idéia nietzschiana de que "a vida acaba onde o "Reino de Deus” começa” (NIETZSCHE, 2006, p. 36), pois esse estado jubiloso apresentado por Jesus como uma experiência possível de ser vivenciada por toda pessoa que plasma a sua existência através dos afetos beatíficos, da alegria e da comunhão, acaba por se distorcer, no contexto da ideologia sacerdotal cristã, numa promessa metafísica de cunho moral. O "Reino de Deus" de Jesus, uma realidade sagrada já dada na imanência, se converte em expectação futura mediante a autoridade moral da instituição sacerdotal.

Talvez uma das chaves que nos permitem decifrar essa idéia de "idiota” na vivência crística se encontre, no contexto da narrativa evangélica, na cena em que Jesus diz publicamente que "o seu Reino não é deste mundo". ${ }^{3}$ Essa sentença não deve ser interpretada fora do contexto axiológico na qual ela é pronunciada, que é justamente o esclarecimento daquilo que vem a ser o projeto evangélico de Jesus, mais precisamente o de proporcionar a cada pessoa uma vivência beatífica destituída de qualquer adequação dessa experiência religiosa ao âmbito extensivo do poder e da organização social. Ao contrário das esperanças messiânicas dos judeus depositadas na ansiada instauração de um onipotente Reino Divino na Terra tal como um Estado político propriamente dito, o "Reino de Deus" de Jesus está além de qualquer definição concreta, não encontrando assim qualquer paralelo com a ordem extensiva da realidade. É então a partir dessas características que se estabelece uma axiologia do "idiota” na prática evangélica, mediante a negativa de qualquer pretensão política acerca do

\footnotetext{
3 "Meu reino não é deste mundo. Se meu reino fosse desse mundo, meus súditos teriam combatido para que eu não fosse entregue aos judeus. Mas meu reino não é daqui" (João, 18, 36).
} 
advento do "Reino de Deus", em verdade um estado destituído de temporalidade e concretude material. O "idiota" se constitui como uma pessoa original, própria, autêntica, pois ele não combina, de forma instintiva, com as características degenerativas do espírito de rebanho, que se expressa justamente pelas categorias do "comum" e do "idêntico". A tipologia do "idiota” representa assim uma pessoa de caráter "extra-social”, que não se enquadra nos critérios normativos da coletividade. Jesus vivia apenas em unidade consigo mesmo e o simbolismo em torno do qual ele orbitava estava inevitavelmente à margem de todo requinte político, artístico ou científico (BARROS, 2002, p.63). Acompanhando a argumentação de Müller-Lauter, podemos até mesmo afirmar que a atividade evangélica de Jesus e seus próprios valores intrínsecos estavam além de toda a moral (MÜLLERLAUTER, 1999, p. 53).

Na própria narrativa bíblica encontramos a corroboração dessa idéia, quando Jesus, ao ser denominado "bom" por um homem admirado por suas qualidades, rechaça tal titulação, afirmando que apenas "Deus" pode ser considerado como tal. ${ }^{4}$ Todavia, podemos defender a tese de que, para Jesus, a idéia de "bem" e da "bondade" em Deus não se sustenta a partir de uma perspectiva moralista, mas na expressão da sua própria beatitude, experimentada por toda pessoa que se sente unificada intrinsecamente ao âmbito divino, e tal associação sagrada se dá na própria realidade imanente, sem depender de qualquer preceito moral. Conforme a interpretação de Eugen Biser acerca da interpretação nietzschiana sobre a práxis evangélica de Jesus, "o Cristianismo originário é a infância livre de toda discórdia e contradição e acolhida ao mesmo tempo no espiritual, um ser-homem que descansa ingenuamente em si mesmo" (BISER, 1974, p.122).

Nietzsche considera Jesus um exemplo de "espírito livre", pois o Nazareno, no decorrer de sua práxis evangélica, não dependeu da ordem moral estabelecida para elaborar a sua axiologia crística: "Seria possível, com alguma tolerância da expressão, chamar Jesus 'um espírito livre' - ele não faz caso do que é fixo: a palavra mata, tudo o que é fixo mata” (NIETZSCHE, 2007, p. 39). Nessas circunstâncias, o filósofo retoma uma problemática axiológica enunciada na época de Humano, demasiado humano, que compõe precisamente o subtítulo desta obra: "Um livro para espíritos livres"; estes são

\footnotetext{
4 "Certo homem de posição Ihe perguntou: 'Bom Mestre, que devo fazer para herdar a vida eterna?" Jesus respondeu: 'Por que me chamas bom? Ninguém é bom, senão só Deus!' (Lucas, 18, 18-19).
} 
aqueles tipos singulares que conseguiram se posicionar acima das limitações de uma dada época histórica, que tiveram a disposição de se colocarem acima dos dogmas e dos preconceitos estabelecidos. A justificativa para tal denominação, conforme se evidencia pela leitura de Nietzsche, decorre do fato de Jesus propor uma experiência religiosa que se distancia da moralidade judaica desgastada pelo formalismo ritualístico dos seus sacerdotes apegados cegamente aos parâmetros da Lei Mosaica. A perpetuação dessa tradição vazia motivou o afastamento dos fiéis judeus da prática religiosa efetiva, ocorrendo assim o distanciamento do homem em relação ao âmbito divino por causa da hierarquia sacerdotal, que, ao invés de servir de catalisador do processo de interação do devoto para com a esfera divina, na verdade acaba por desligar essa conexão sagrada, estatuindo a idéia de "Deus" como uma personalidade transcendente ao mundo que somente pode ser alcançada mediante o cumprimento de ritos específicos. Parafraseando o discurso evangélico, podemos dizer que o sistema de poder sacerdotal, além de não conseguir estabelecer conexão religiosa com a dimensão divina, não deixa que os demais membros do rebanho também o façam. ${ }^{5}$ A moral sacerdotal pretende até mesmo impor o modo pelo qual o indivíduo deve direcionar a sua consciência para Deus, a fim de que todos os fiéis sigam um sistema único de devoção. Em nome dessa uniformidade de preceitos, ocorre a separação do indivíduo com a esfera sagrada, e assim a supressão do estado de beatitude.

Contrapondo-se a essa concepção normativa que rejeita a singularidade da experiência religiosa, Jesus, como um "espírito livre”, visaria o desenvolvimento de uma experiência religiosa da alegria, capaz de proporcionar a geração de sentimentos afirmativos, que suprimiriam as vivências tristes e depressivas da afetividade humana. O amor crístico, configurado pela própria experiência da mensagem evangélica, viabilizaria o nascimento de um sentimento de comunhão através da descoberta da unidade mística fundamental, que proclama a idéia de que todos os seres humanos são "filhos de Deus", cada um é igual a todos, sem qualquer restrição, tal como destacado por Nietzsche (2007, p. 36).

Toda a idéia que se faz de Jesus como aquele que sofreu para redimir a humanidade das suas faltas, assim como da imagem da Paixão como recurso destinado a exercer efeito moral sobre a consciência dos fiéis não

\footnotetext{
5 "Ai de vós, escribas e fariseus, hipócritas, porque bloqueais o Reino dos Céus diante dos homens! Pois vós mesmos não entrais, nem deixais entrar os que querem!" (Mateus, 23, 13-14).
} 
corresponde ao genuíno espírito crístico, que suprime justamente toda noção de dívida moral a ser quitada pelo ser humano diante de Deus ao longo de sua história de redenção. A Paixão, que representaria a culminação gloriosa da obra evangélica de Jesus, na qual se demonstra efetivamente a beatitude na sua forma mais extraordinária mediante a supressão de qualquer disposição rancorosa, se torna o mecanismo teológico que reteria a individualidade dos fiéis diante dos seus parâmetros normativos. Para Nietzsche,

Esse "portador da boa nova" morreu como viveu, como ensinou - não para "redimir os homens", mas para mostrar como se deve viver. A prática foi o que ele deixou para a humanidade: seu comportamento ante os juízes, ante os esbirros, ante os acusadores e todo tipo de calúnia e escárnio seu comportamento na cruz. Ele não resiste, não defende seu direito, não dá um passo para evitar o pior; mais ainda, ele provoca o pior... E ele pede, ele sofre, ele ama com aqueles, naqueles que the fazem mal... As palavras que ele diz ao ladrão na cruz contêm todo o evangelho. "Este foi verdadeiramente um homem divino, um filho de Deus" - diz o ladrão. "Se sentes isso - responde o Salvador - "então estás no paraíso, és também um filho de Deus..." Não defender-se, não encolerizar-se, não atribuir responsabilidade... mas tampouco resistir ao mau - amá-lo... (NIETZSCHE, 2007, p. 42).

Mediante a colocação precedente, podemos defender a idéia de que a compreensão do espírito crístico originário está no preceito evangélico de "não resistirmos ao homem mau" e "amarmos os nossos inimigos" (Mateus, 5, 39-44). A aplicação efetiva de tais prédicas nos impede de levantarmos oposições violentas contra nossos possíveis detratores mesmo nas condições mais desfavoráveis, pois a vivência evangélica de antemão rompe com os parâmetros valorativos da realidade cotidiana, e o fato do indivíduo lutar por seus direitos e tomar parte na ordem estabelecida é contradizer a liberdade

\footnotetext{
${ }^{6}$ É importante salientar que Nietzsche cometera um equívoco de citação ao colocar na boca do ladrão (Lucas, 23, 39-43), a frase na qual se proclama a divindade de Jesus, quando na verdade teria sido um centurião romano que fazia a guarda no Calvário que enunciara essa sentença, após a morte de Jesus. (Mateus, 27, 54). Todavia, no contexto de sua interpretação da vivência crística, pouca diferença isso faz. Em qualquer circunstância, se evidencia a epifania evangélica de Jesus. Obviamente que é importante destacarmos esse acontecimento de forma precisa, por um respeito filológico ao texto evangélico.
} 
existencial proporcionada pela aplicação dessa disposição evangélica, que é uma contínua abertura para o perdão e para a capacidade de amarmos incondicionalmente qualquer pessoa. A capacidade beatífica de não se resistir ao "mal" significa a supressão de todo tipo de reatividade e violência diante dos desagravos sofridos nas vivências cotidianas.

Há que se destacar ainda que a formulação do final da citação precedente é extremamente semelhante à que Nietzsche utiliza no Ecce Homo para definir o conceito de amor fati: "Minha fórmula para a grandeza do homem é amor fati: nada querer diferente, seja para trás, seja para a frente, seja em toda a eternidade. Não suportar apenas o necessário, menos ainda ocultá-lo - todo idealismo é mendacidade ante o necessário mas amá-lo... (NIETZSCHE, 2001, p. 51). ${ }^{7}$ Uma pergunta então se torna inevitável: porventura Nietzsche identifica na Paixão de Jesus uma espécie de vivência do amor fatt? Com efeito, o Nazareno afirmou a dor na Cruz sem formular qualquer imprecação contra os seus agressores; mais ainda, nada fez para afastar de si esse destino, obtendo assim uma morte beatífica, sem a erupção de qualquer ressentimento contra a vida ou contra a ordem estabelecida. Curiosamente, mesmo involuntariamente, aquele que pratica a não-resistência se transforma em um surpreendente antípoda da ordem dominante e acaba por desmascarar a própria impossibilidade de uma comunidade religiosa ou política abrir mão dos instrumentos coercitivos de que dispõe (BARROS, 2002, p. 66). Conforme argumenta Christoph Türcke,

Não resistir ao mau, amar também seus inimigos: isto nenhuma lei do mundo se pode permitir - nenhuma que mantenha coesa uma comunidade religiosa ou política, e nem sequer uma que dê sustentáculo moral a uma alma. Onde há ordem jurídica ou moral aí há lei. Porém, constitui justamente a definição de lei que ela tenha um inimigo: o que se desvia dela, o proibido. E ela só dura enquanto se comporta de fato hostilmente contra este inimigo, não tolera o proibido e busca extingui-lo através do castigo (TÜRCKE, 1993, p, 186).

Por sua vez, o ato de se interpretar a Paixão de Jesus como a esperança de redenção espiritual mediante o sacrifício do "Cristo-Cordeiro de Deus"

${ }^{7}$ Para mais detalhes da problematização nietzschiana sobre o amor fati, cf. Rubira, 2008, p. 227-236. 
que tomou os nossos pecados, denota a incompreensão da mensagem evangélica originária, que, malgrado o ter sido modificada ao gosto escuso dos detentores do discurso eclesiástico oficial, pode, todavia, ser apreendida intuitivamente pela vivência psicológica (GIACÓIA Jr., 1997, p. 48). Como Nietzsche ressalta de modo veemente, a morte de Jesus é utilizada pela casta sacerdotal como instrumento de reparação moral em relação aos fiéis, deturpando assim o sentido originário dessa experiência de comunhão com o sagrado:

- O destino do evangelho foi decidido com a morte - foi pendurado na "cruz..." Somente com a morte, essa morte inesperada, ignóbil, somente a cruz, geralmente reservada para a canaille [canalha] - somente esse horrível paradoxo pôs os discípulos ante o verdadeiro enigma: "quem foi esse? $O$ que foi isso?." - O sentimento abalado e profundamente ofendido, a suspeita de que tal morte poderia ser a refutação de sua causa, a terrível interrogação "por que justamente assim?" - é um estado que se compreende muito bem. Tudo aí tinha de ser necessário, ter sentido, razão, suprema razão; o amor de um discípulo não conhece acaso. Apenas então o abismo se abriu: "quem o matou? quem era seu inimigo natural?” - essa questão irrompeu como um raio. Resposta: o judaísmo dominante, sua classe mais alta. Nesse instante sentiram-se em revolta contra a ordem, entenderam Jesus, em retrospecto, como em revolta contra a ordem. Até ali faltava, em seu quadro, esse traço guerreiro, essa característica de dizer o Não, fazer o Não; mais até, ele era o contrário disso. Evidentemente, a pequena comunidade não compreendeu o principal, o que havia de exemplar nessa forma de morrer, a liberdade, a superioridade sobre todo sentimento de ressentiment [ressentimento]: - sinal de como o entendia pouco! Jesus não podia querer outra coisa, com sua morte, senão dar publicamente a mais forte demonstração, a prova de sua doutrina... Mas seus discípulos estavam longe de perdoar essa morte - o que teria sido evangélico no mais alto sentido; ou mesmo de oferecer-se para uma morte igual, com meiga e suave tranqüilidade no coração... Precisamente o sentimento mais "inevangélico", a vingança, tornou a prevalecer. A questão não podia findar com essa morte: necessitava-se de "reparação", "julgamento" (- e o que pode ser menos evangélico do que "reparação", "castigo", "levar a julgamento”!). Mais uma vez a 
expectativa popular de um Messias apareceu em primeiro plano; enxergou-se um momento histórico: o "reino de Deus" como ato final, como promessa! Mas o evangelho fora justamente a presença, a realização, a realidade desse "reino de Deus"... Pela primeira vez carrega-se todo o desprezo e amargor contra fariseus e teólogos para o tipo do mestre - tornando-o assim um fariseu e teólogo! Por outro lado, a frenética veneração dessas almas totalmente saídas dos eixos não mais tolerou a evangélica identificação de cada um como filho de Deus, que Jesus havia ensinado: sua vingança foi exaltar extravagantemente Jesus, destacá-lo de si: assim como os judeus de outrora, por vingança contra os inimigos, haviam separado de si e erguido às alturas o seu. $\mathrm{O}$ único Deus e o único filho de Deus: ambos produtos do ressentiment... (NIETZSCHE, 2007, p. 46-48).

Nietzsche também considera haver uma incongruência axiológica no dogma da Ressurreição, pois a visão de mundo cristã fez da crença nesse acontecimento condição sine qua non para o estabelecimento de sua experiência religiosa, quando, na verdade, a história dos Evangelhos por si só já deveria servir de instrumento capaz de reforçar as disposições beatíficas dos fiéis, despertando-lhes imediatamente alegria e disposições amorosas para com todos os circundantes. Nessas condições, o caráter mais extraordinário da genuína prática crística não depende da ocorrência de "milagres" que sirvam de confirmação da autoridade sagrada de Jesus, mecanismo tão bem articulado pelo discurso teológico cristão, mas da capacidade de cada pessoa viver efetivamente na esfera transfiguradora de sua própria existência mediante a participação no amor divino. Conforme argumenta Nietzsche,

- A partir de então houve um problema absurdo: "como podia Deus permitir isso?” A perturbada razão da pequena comunidade deu-lhe uma resposta assustadoramente absurda: Deus deu seu filho em sacrifício para o perdão dos pecados. De uma só vez acabou-se o evangelho! O sacrifício expiatório, e em sua forma mais bárbara e repugnante, o sacrifício do inocente pelos pecados dos culpados! Que pavoroso paganismo! - Jesus havia abolido o próprio conceito de "culpa" - ele negou todo abismo entre Deus e homem, ele viveu essa unidade de Deus e homem como sua "boa nova"... E não como prerrogativa! - A partir de então entra no tipo do 
Redentor, passo a passo, a doutrina do julgamento e do retorno, a doutrina da morte como uma morte sacrificial, a doutrina da ressurreição, com a qual é escamoteado o conceito de "beatitude", a única realidade do evangelho - em prol de um estado posterior à morte!... Com a insolência rabínica que sempre o caracteriza, Paulo racionalizou esta concepção, esta obscenidade de concepção, da seguinte forma: "Se Cristo não ressuscitou de entre os mortos, é vã a nossa fé" [1 Coríntios, 15,14], - E de uma só vez o evangelho se tornou a mais desprezível das promessas não realizáveis, a desavergonhada doutrina da imortalidade pessoal... O próprio Paulo ainda a ensinava como recompensa!... (NIETZSCHE, 2007, p. 48).

Para malgrado da possibilidade de afirmação de uma experiência crística na história da Cristandade, a idéia da Ressurreição se tornou então um instrumento de dominação teológica mediante a necessidade do rebanho de fiéis acreditar incondicionalmente nesse dogma, e não a certeza da perpetuação da "vida", para além da "morte" e das suas figurações singulares. Aliás, a própria idéia de "hora da morte", tão enaltecida para a moralidade cristã não faz sentido algum para a experiência evangélica, talvez seja mesmo a sua antagonista por excelência. Para Nietzsche,

Todo o conceito de morte natural está ausente no evangelho: a morte não é uma ponte, uma passagem, ela não está presente, pois pertence a um mundo inteiramente outro, apenas aparente, útil apenas para signos. A "hora da morte" não é um conceito cristão - a "hora", o tempo, a vida física e suas crises não chegam a existir para aquele que ensina a "boa nova”... (NIETZSCHE, 2007, p. 41-42)

A beatitude crística exclui da consciência do participante de tal estado religioso toda consideração pelo morrer, e talvez até mesmo pelo viver enquanto mera extensividade, ou seja, enquanto mera adequação da existência segundo os critérios quantitativos da vida em sociedade (acúmulo de bens, promoção pessoal), pois a alegria evangélica transforma radicalmente a própria individualidade, imergindo-a numa experiência divina que concede ao devoto um gozo inefável que o coloca afetivamente para além do tempo cronológico. Nessas circunstâncias, o memento mori, isto é, a lembrança moral da 
iminência da morte, pode ser considerada como um sintoma de adoecimento psíquico e afastamento da beatitude crística, pois esta se encontra numa esfera axiológica que rompe com os paradigmas extensivos de "vida" e "morte".

A experiência cristã original se realiza na própria imanência e nos permite ver que o Reino dos Céus não está acima do mundo físico, da Terra, mas se encontra imediatamente unido a ela. É por isso que, de acordo com os Evangelhos, Jesus teria afirmado que o "Reino de Deus está dentro de nós." (Lucas, 17, 21). Ao interpretar esse trecho bíblico, Nietzsche realiza no $§ 34$ d'O Anticristo uma espécie de paráfrase da mensagem do Nazareno, afirmando que

O "reino do céu" é um estado de coração - não algo que virá "acima da Terra" ou "após a morte" [...] O Reino de Deus não é nada que se espere; não possui ontem nem depois de amanhã, não virá em "mil anos" - é a experiência de um coração; está em toda parte, está em nenhum lugar... (NIETZSCHE, 2007, p.41-42).

Evidencia-se nessa idéia nietzschiana o descarte radical do milenarismo escatológico presente no Apocalipse (20,4), interpretado sob uma perspectiva moralizante pela Igreja Cristã no decorrer dos séculos, na crença de que Jesus retornaria para julgar o mundo e exaltar os “justos”. Mais ainda, a crença estabelecida na existência de uma dimensão divina para além do mundo também é abalada, o que de modo algum retira da vivência crística a sua dinâmica sagrada, pois não é condição indispensável para a experiência da beatitude que exista um mundo supra-sensível denominado como "Céu", "Paraíso". Se Jesus enfatizou que o "Reino dos Céus" se encontra na própria interioridade humana, isso significa que não é de modo algum necessária a adequação pessoal a critérios normativos externos, ou seja, a submissão da consciência perante os ditames de uma casta sacerdotal, pretensamente detentora do método moral que conduz ao "Paraíso".

O "Reino dos Céus" é uma experiência religiosa sustentada por uma valoração "amoral”, o que exclui então qualquer dependência do indivíduo aos critérios normativos de uma doutrina religiosa. Podemos considerar esse "estado de coração" descrito por Nietzsche como o inefável estado afetivo caracterizado pela presença marcante de um sentimento de júbilo e de bemestar íntimo na vida do indivíduo que compreende a existência de uma unidade amorosa que envolve todos os seres humanos, ainda que estes, de uma forma geral, desconheçam completamente esse júbilo originário. Esse 
dito "Reino dos Céus" não necessita de modo algum estar situado em uma dimensão espiritual supra-sensível, conforme a instituição teológica que se desenvolveria mediante o legado evangélico de Jesus viria a instituir dogmaticamente e a massa de fiéis viria a acatar passivamente, através da idéia da existência de um "Paraíso" situado para além do mundo efetivo em que vivemos. O "Reino dos Céus" é intrinsecamente desprovido de extensividade, e essa sua característica primordial o torna uma experiência jubilosa desvinculada da participação pessoal nos parâmetros morais estabelecidos pela ordem sacerdotal, circunstância que seria, na verdade, a sua tristonha supressão, pois a moral religiosa depende da contínua tristeza dos seus fiéis para obter o crescente poder sobre as suas aspirações individuais.

Nietzsche focaliza a sua perspectiva valorativa para o caráter de pura intensidade na interpretação simbólica deste referido "Reino dos Deus", que consiste assim na própria ausência da idéia de fixidez e de delimitação extensiva e temporal diante da imagem que a Cristandade faz do suposto Plano Divino, considerado separado ontologicamente do mundo terreno. Presente intensivamente em cada coração que vivencia o estado crístico, o Plano Divino não se manifesta extensivamente na realidade social, mas é um desabrochar singular no íntimo de cada pessoa. Nietzsche exclui então da idéia estabelecida do "Reino de Deus" a expectativa teleológica de um poder divino a se sobrepor sobre a ordem do mundo, para julgar toda a humanidade por seus atos ao longo das eras (NIETZSCHE, 2007, p. 21). O "Reino de Deus" tal como revelado metaforicamente por Jesus não possui traços milenaristas, conforme os teólogos e doutores da fé cristã posteriormente consolidariam como verdades inquestionáveis. O dito "Reino de Deus" não é um evento escatológico, mas uma vivência na eternidade do afeto de amor e comunhão dos homens. Jesus demonstrara para aqueles que se abriram sinceramente aos seus ensinamentos que, para alguém se sentir no "Céu", para se sentir "eterno", é necessário se desenvolver uma nova compreensão da existência, que por sua vez gera um novo comportamento, justamente livre de todo entravamento, temor ou rancor diante do mundo. Para Jesus, o "Reino de Deus" não pode ser pensado como promessa de um paraíso ultramundano, mas como vivência plena e atemporal do amor e da renúncia a toda oposição, a toda forma de ressentimento (GIACÓIA Jr., 1997, p. 39).

A alegria e o amor dissolvem as limitações pessoais que impedem o afloramento da consciência de que a vida no júbilo crístico torna alguém "eterno" (NIETZSCHE, 2007, p. 41). O "Reino de Deus", tal como 
compreendido por Nietzsche, se encontra na disposição afetiva de todo aquele que é capaz de vivenciar a realidade circundante através da perspectiva da alegria e do amor, considerando a configuração do mundo circundante como uma força constituinte de seu próprio âmago, pois não existe mais barreira que separe o indivíduo imerso na experiência crística do mundo ao redor. Tudo passa a fazer parte de uma grande unidade imanente, permeada pelo espírito de alegria que unifica todos os seres: trata-se da beatitude e da inocência do homem livre do peso do ressentimento e do medo, instrumentos de dominação moral utilizados pela casta sacerdotal cristã.

Quando Jesus enuncia aos seus discípulos a sentença "Eu e o Pai somos um" (João, 10, 30), dá testemunho de um nítido monismo, pois o distanciamento entre o divino e o humano, tão destacado pela casta sacerdotal judaica como forma de motivar o estristecimento do fiel, em verdade inexiste. Para que se estabeleça essa vivência transfiguradora, somente é necessário o amor, a quietude íntima, jamais a adequação individual a preceitos normativos e fórmulas mortas. Ora, dizer que o estado beatífico promove a identificação imediata entre o humano e o divino é uma idéia desfavorável para os detentores do poder eclesiástico, decorrendo daí os ressentimentos dos fariseus perante o carisma de Jesus, que apregoava de maneira nítida a possibilidade de cada um compreender a unidade com o "Pai". Nietzsche considera que, com a palavra "Filho" se expressa a entrada no sentimento geral de transfiguração de todas as coisas (a beatitude), e com a palavra "Pai", esse sentimento mesmo, o sentimento de eternidade, de perfeição (NIETZSCHE, 2007, p. 41). Por meio desses símbolos, Nietzsche enfatiza precisamente a relação de unicidade entre ambas as esferas, intrinsecamente complementares, ainda que expressem perspectivas axiológicas distintas. Esse monismo que associa ontologicamente as figuras do "Pai" e do "Filho" proporciona a integração de ambos numa única pessoa, e é o amor que gera essa associação, que somente pode ser vivenciada pelo coração, pois é uma experiência extra-racional. A atividade evangélica de Jesus consistiu justamente em motivar nos seus seguidores a capacidade de cada um alcançar esse estado sagrado de júbilo, pois essa relação suprime da vida humana todo sentimento de temos e tristeza. Conforme os elucidativos comentários de Oswaldo Giacóia Jr.,

Essa prática de interiorização do Reino de Deus implica, senão uma negação explícita, doutrinária e formal da Igreja entendida como realidade exterior, organizada segundo princípios, 
hierarquias, regramentos, pelo menos sua superação e supressão necessárias na práxis, no seio de uma vivência quotidiana de comunhão universal com o "Pai" e o "Próximo" que abole todas as distâncias (GIACÓIA Jr., 1997, p. 77).

A beatitude vivenciada por Jesus não combina, de forma instintiva, com hierarquias consolidadas pela autoridade social; esse novo estado religioso prima, isso sim, pela capacidade singular de cada um se libertar dos entraves afetivos que prejudicam a participação nessa experiência de amor divino. ${ }^{8}$ Esse "estado de coração" se manifestaria em quem viesse a despertar um conjunto de afetos benéficos para o desenvolvimento saudável da vida, tais como o amor incondicional diante do outro e a magnânima capacidade de perdoar as ofensas sofridas, suprimindo-se assim os estados rancorosos da afetividade, que afastam o indivíduo da esfera crística (Mateus, 5, 43-44). Para Nietzsche,

A vida do Redentor não foi senão essa prática - sua morte também não foi senão isso... Ele não tinha mais necessidade de nenhuma fórmula, de nenhum rito para o trato com Deus - nem mesmo oração. Acertou contas com toda a doutrina judaica da penitência e reconciliação; sabe que apenas com a prática de vida alguém pode sentir-se 'divino', 'bem-aventurado', 'evangélico', a qualquer momento um 'filho de Deus'. Não a "penitência”, não a oração pelo perdão' é um caminhos para Deus: somente a prática evangélica conduz a Deus, ela justamente é Deus - O que foi liquidado com o evangelho foi o judaísmo dos conceitos "pecado", "perdão dos pecados", "fé”," "redenção pela fé" - toda a doutrina eclesiástica judia foi negada na "boa nova” (NIETZSCHE, 2007, p.40-41).

Uma vez que a prática evangélica é "Deus", pela palavra "Deus" não devemos então entender uma personalidade, mas um estado de beatitude indizível, manifestado na interioridade daquele que atinge tal nível de júbilo diante da realização de ações e de pensamentos de amor, de beleza, de

\footnotetext{
${ }^{8}$ Apesar de Nietzsche pretender desconsiderar axiologicamente as considerações de Renan sobre os conceitos de "Herói" e "Gênio" na personalidade de Jesus, a cristologia do historiador francês não pode ser invalidada de todo, como podemos ver na seguinte citação: "Um culto puro, uma religião sem sacerdotes e sem práticas exteriores, baseando-se toda nos sentimentos do coração, na imitação de Deus, na imediata relação da consciência com o Pai Celeste, eram as conseqüências desses princípios" (Nietzsche, 1915, p. 70-71).
} 
serenidade, decorrentes da certeza de que se vive intimamente unificado ao âmbito "divino". Para Christoph Türcke,

Se o único que merece o nome "Deus" é a prática evangélica, o "não-poder-ser-inimigo", então a vida de Jesus já era o ataque geral a tudo mais que se entendia por "Deus", e que sensatamente se tem também de entender: uma subjetividade sobrenatural, que age como criador e garante uma ordem moral de mundo, como justificador do egocentrismo da razão humana, como salvador, da miséria, para a salvação dos homens (TÜRCKE, 1993, p. 196).

"Deus", muito mais do que uma personalidade tal como compreendida pela visão tradicional do "monótonoteismo", seria um núcleo de forças intensivas em contínua expansão na pessoa tomada por esse sentimento de amor sem fronteiras. O Deus do monoteísmo judaico-cristão é oposto ao "divino". 9 Imerso nessa dimensão beatífica, o ser humano, para relacionar-se com o âmbito divino, não necessitaria nem de fórmulas preestabelecidas, muito menos ritos, pois somente através da prática de vida, tal como Nietzsche salienta, alguém pode se sentir "divino", "bem aventurado", "evangélico", um "Filho de Deus”, vivendo em estado de júbilo e livre do sentimento de pecado e de toda coerção moral. Na psicologia do "evangelho" não há os conceitos de "culpa" ou "castigo" (NIETZSCHE, 2007, p. 40). Para aquele que vive intensamente imerso na interação imediata com o "divino", os rituais e as orações, se tornam elementos secundários, pois que não são mais práticas imprescindíveis para que possa ocorrer o contato com a esfera sagrada, pois o indivíduo já se encontra nessa esfera sagrada, ele na verdade vive nela. Não há, tampouco, a necessidade da crença numa dimensão espiritual ontologicamente e axiologicamente superior ao mundo em que vivemos, pois que na própria experiência religiosa podemos nos preencher afetivamente com a alegria da interação com a divindade. Nessa perspectiva, Nietzsche, demonstrando uma surpreendente visão pessoal acerca da experiência religiosa proporcionada pela imanência da disposição crística, considera que

9 Para mais detalhes dessa questão, Cf. Taha, p. 13. 
O profundo instinto para como alguém deve viver a fim de sentir-se "no céu", sentir-se "eterno", enquanto, conduzindo-se de qualquer outro modo, não se sente absolutamente no céu: apenas esta é a realidade psicológica da "redenção": - uma nova conduta, não uma nova fé... (NIETZSCHE, 2007, p. 41).

A práxis evangélica em sua acepção originária representa, portanto, a possibilidade de instauração de uma vivência religiosa destituída da virulência do ressentimento e de toda coerção normativa na consciência daquele que, mediante o amor crístico, se relaciona imediatamente ao divino, emancipado da moral sacerdotal e dos seus efeitos deletérios na possibilidade de formulação de uma prática religiosa efetivamente "alegre", para além da dimensão moralista de "Bem" e "Mal"

\section{REFERÊNCIAS BIBLIOGRÁFICAS:}

A BÍBLIA DE JERUSALÉM. Direção Editorial de Paulo Bazaglia. São Paulo: Paulus, 2002.

BARROS, F. de M. A Maldição Transvalorada: o problema da civilização em O Anticristo de Nietzsche. São Paulo: Discurso Editorial, 2002.

BISER, E. Nietzsche y la destruccion de la conciencia cristiana. Trad. de Josué Enzaguirre. Salamanca: Ediciones Sigueme, 1974.

CHATEuAubriand, F.-R. de. O Gênio do Cristianismo. 2 v. Trad. de Camilo Castelo Branco. Porto: Chardon de Lello \& Irmãos, 1945.

DOSTOIÉVSKI, F. O Idiota. Trad. de Paulo Bezerra. São Paulo: Ed. 34, 2002.

FREZZATTI Jr., W. A. A Fisiologia de Nietzsche: a superação da dualidade cultura/biologia. Ijuí: Ed.Unijuí, 2006.

GIACÓIA Jr., O. Os labirintos da alma - Nietzsche e a auto-supressão da Moral. Campinas: Ed. Unicamp, 1997.

MÜLLER-LAUTER, W. Nietzsche: His philosophy of contradictions and the contradictions of his philosophy. Trad. de David J. Parent. Illinois: Illinois University Press, 1999.

NIETZSCHE, F. Sämliche Werke. Kritische Studienausgabe. Edição 
organizada por Giorgio Colli e Mazzino Montinari. 15 Vols. Berlim: Walter de Gruyter, 1980.

. O Anticristo / Ditirambos de Dionísio. Trad. de Paulo César de Souza. São Paulo: 2007.

. Crepúsculo dos Ídolos ou como se filosofa com o martelo. Trad. de Paulo César de Souza. Companhia das Letras: São Paulo: 2006.

- Ecce Homo - como alguém se torna o que se é. Trad. de Paulo César de Souza. São Paulo: Companhia das Letras, 2001.

. Humano, demasiado humano - um livro para espíritos livres. Trad. de Paulo César de Souza. São Paulo: Companhia das Letras, 2002.

RENAN, E. São Paulo. Trad. de Thomaz da Fonseca. Porto: Chardon de Lello \& Irmãos, 1945.

- Vida de Jesus. Trad. de Eduardo Augusto Salgado. Porto: Chardon de Lello \& Irmãos, 1915.

RUBIRA, L. "O amor fati em Nietzsche: condição necessária para a transvaloração?” In: Polymátheia (UECE), v. IV, p. 227-236, 2008.

TAHA, A. Le Dieu à venir de Nietzsche ou la rédemption du divin. Paris: Connaissances et Savoirs, 2005.

TÜRCKE, C. O Louco: Nietzsche e a mania da razão. Trad. de Antônio Celiomar Pinto de Lima. Petropólis: Vozes, 1993.

UHL, A. "Dor por Deus e dor pelo Homem: Nietzsche e Dostoievski”, In: Nietzsche e o Cristianismo. Trad. de Waldemar do Amaral. Petrópolis: Vozes, 1981, p.43-55. 